\title{
Sytuacja na rynku produktów owczarskich na świecie w latach 1997-2001
}

Owce mogą być źródłem wielu surowców: wełny, skór, mięsa, mleka, a także nawozów o bardzo wysokiej zawartości składników mineralnych. W ostatnich latach odkryto wyjątkowe właściwości naturalnego składnika mleka i mięsa owiec, sprzężonego kwasu linolowego. To odkrycie stworzyło nowe możliwości kształtowania właściwości tych produktów. Sprzężony kwas linolowy ma wiele właściwości prozdrowotnych, m.in. pełni rolę czynnika zapobiegającego otyłości, antymiażdżycowego, antynowotworowego, hamującego osteoporozę i stymulującego układ odpornościowy.

\section{Pogłowie owiec na świecie}

Produkcja mięsa, mleka i innych produktów owczarskich determinowana jest przez liczebność światowej populacji owiec (tab. 1). Ze względu na dużą liczbę państw, w których ma miejsce chów i hodowla owiec (około 100), w tabeli umieszczono jedynie kraje posiadające najliczniejsze pogłowie.

Tabela 1

Pogłowie owiec w poszczególnych krajach w latach 1997-2001

\begin{tabular}{|l|r|r|r|r|r|}
\hline \multirow{2}{*}{ Wyszczególnienie } & \multicolumn{5}{|c|}{ Liczba owiec w latach [tys. sztuk] } \\
\cline { 2 - 6 } & 1997 & 1998 & 1999 & \multicolumn{1}{c|}{2000} & \multicolumn{1}{c|}{2001} \\
\hline Swiat & 1051600 & 1052855 & 1053788 & 1057131 & 1046372 \\
\hline Chiny & 114125 & 120956 & 127352 & 131095 & 133160 \\
\hline Australia & 120228 & 117491 & 115456 & 118552 & 116200 \\
\hline Indie & 56472 & 57100 & 57600 & 57900 & 58200 \\
\hline Iran & 52117 & 53245 & 53900 & 53900 & 53900 \\
\hline Sudan & 39835 & 42363 & 44802 & 46095 & 47042 \\
\hline Nowa Zelandia & 46834 & 45956 & 45956 & 45385 & 44002 \\
\hline Wielka Brytania & 42823 & 44471 & 44656 & 42261 & 36697 \\
\hline RPA & 29187 & 29345 & 28680 & 28551 & 28800 \\
\hline
\end{tabular}

Źródło: opracowanie własne na podstawie FAOSTAT. 
Liczebność owiec w latach 1997-2000 pozostawała na niezmienionym poziomie. W poszczególnych krajach tendencje były zróżnicowane. W większości państw pogłowie utrzymało się na podobnym poziomie. W Sudanie zwiększono pogłowie owiec w latach 1997-2001 o 18\%. Tendencje wzrostowe występowały w Chinach, gdzie wzrost pogłowia wyniósł $16,7 \%$, dzięki czemu Chiny wyprzedziły Australię, która do tej pory miała najliczniejsze pogłowie. W Australii pogłowie zmniejszyło się o około $4 \mathrm{mln}$ szt.

Liczebność owiec w krajach UE przedstawia tabela 2. W tym ugrupowaniu najliczniejsze pogłowie posiadała Wielka Brytania. Mimo spadku o 14,3\% w latach 1997-2001 nadal zajmowała ona pierwsze miejsce. Największy wzrost liczebności owiec nastapił w Irlandii (o 39\%). Drastycznie spadła natomiast liczebność owiec w Portugalii (43,2\%). Mniej owiec było także we Francji (o 10,9\%) i Holandii (11,5\%). Większość krajów zachowało dotychczasowy poziom pogłowia owiec.

Tabela 2

Pogłowie owiec w poszczególnych krajach UE w latach 1997-2001

\begin{tabular}{|l|r|r|r|r|r|}
\hline \multirow{2}{*}{ Kraje } & \multicolumn{5}{|c|}{ Liczba owiec w latach [tys. sztuk] } \\
\cline { 2 - 6 } & 1997 & 1998 & 1999 & \multicolumn{1}{c|}{2000} & \multicolumn{1}{c|}{2001} \\
\hline Wielka Brytania & 42823 & 44471 & 44656 & 42261 & 36697 \\
\hline Hiszpania & 23982 & 24857 & 24190 & 23965 & 24400 \\
\hline Włochy & 10943 & 10893 & 10894 & 11017 & 11089 \\
\hline Francja & 10463 & 10316 & 10240 & 9509 & 9324 \\
\hline Grecja & 8896 & 8884 & 8930 & 8732 & 9269 \\
\hline Irlandia & 5391 & 5634 & 5624 & 7637 & 7498 \\
\hline Portugalia & 6300 & 5800 & 5850 & 3584 & 3578 \\
\hline Niemcy & 2324 & 2301 & 2280 & 2150 & 2140 \\
\hline Holandia & 1465 & 1394 & 1401 & 1308 & 1296 \\
\hline Szwecja & 442 & 421 & 437 & 432 & 452 \\
\hline Austria & 380 & 383 & 360 & 351 & 357 \\
\hline Belgia-Luksemburg & 162 & 155 & 158 & 126 & 167 \\
\hline Finlandia & 150 & 128 & 106 & 99 & 96 \\
\hline
\end{tabular}

Źródło: opracowanie własne na podstawie FAOSTAT.

\section{Produkty uzyskiwane od owiec}

Produkty owczarstwa to wełna i żywiec. Wełna w ostatnim czasie straciła na wartości. Najwięksi producenci wełny zostali przedstawieni w tabeli 3 . W światowej produkcji wełny w 2001 roku nastappił spadek o 7,5\% w stosunku do 1997 roku. Największym producentem wełny na świecie była Australia. 
Jednak również w tym kraju produkcja wełny zmniejszyła się w latach 1997-2001 o 16,1\%. Nowa Zelandia zajmowała drugie miejsce w 1997 roku, jednak na skutek spadku o 13,9\% straciła swoją pozycję na rzecz Chin. Chiny znacznie zwiększyły produkcje welny (wzrost o $16,9 \%$ ). W pierwszej „dziesiątce” producentów wełny znajdują się dwa kraje z Europy. W Wielkiej Brytanii spadek produkcji wełny był związany ze zmniejszeniem pogłowia owiec. Turcja natomiast mimo niewielkiego spadku pogłowia zwiększyła produkcję wełny.

\section{Tabela 3}

Produkcja wełny owczej w wybranych krajach w latach 1997-2001

\begin{tabular}{|l|r|r|r|r|r|}
\hline \multirow{2}{*}{ Wyszczególnienie } & \multicolumn{5}{|c|}{ Produkcja welny owczej [tys. ton] } \\
\cline { 2 - 6 } & \multicolumn{1}{|c|}{1997} & \multicolumn{1}{c|}{1998} & \multicolumn{1}{c|}{1999} & \multicolumn{1}{c|}{2000} & \multicolumn{1}{c|}{2001} \\
\hline Świat & 2376,70 & 2343,26 & 2309,94 & 2298,85 & 2199,05 \\
\hline Australia & 700,00 & 687,00 & 671,00 & 652,00 & 587,00 \\
\hline Chiny & 255,06 & 276,76 & 283,15 & 292,50 & 298,25 \\
\hline Nowa Zelandia & 274,80 & 265,80 & 252,00 & 257,20 & 236,66 \\
\hline Iran & 57,00 & 62,70 & 73,91 & 75,00 & 75,00 \\
\hline Argentyna & 68,00 & 62,00 & 65,00 & 58,00 & 58,00 \\
\hline Urugwaj & 81,85 & 75,50 & 60,29 & 54,82 & 53,24 \\
\hline RPA & 57,27 & 53,05 & 56,03 & 52,67 & 52,67 \\
\hline Wielka Brytania & 64,00 & 69,00 & 66,00 & 63,00 & 50,00 \\
\hline Indie & 44,70 & 45,50 & 46,50 & 47,60 & 47,60 \\
\hline Turcja & 45,63 & 44,37 & 45,67 & 46,60 & 46,60 \\
\hline
\end{tabular}

Źródło: opracowanie własne na podstawie FAOSTAT.

Zmniejszanie produkcji wełny wynika przede wszystkim $\mathrm{z}$ pogorszenia koniunktury na produkty wełniane, a w związku $\mathrm{z}$ tym również na wełnę. Wymagania rynku również skłaniają do ,przestawienia się" na kierunek mięsnego użytkowania owiec. Od owiec ras mięsnych uzyskuje się jednak mniej wełny.

Podstawowym produktem uzyskiwanym od owiec stało się mięso. W statystyce często łączy się wyniki produkcyjne owiec i kóz. Tabela 4 przedstawia więc łączną produkcję mięsa owczego (jest to głównie jagnięcina) i koziego. $\mathrm{Na}$ świecie produkcja mięsa owczego i koziego w latach 1997-2001 ulegała wahaniom. Najwyższy jej poziom był w 1998 roku, natomiast najniższy w 2001 roku. Zdecydowanym liderem były Chiny, które zwiększyły produkcję mięsa owczego i koziego w 2001. roku w stosunku do 1997 roku o 37,5\%. Duży wzrost zanotowała również Australia (o 25,8\%), niewielki natomiast Nowa Zelandia (3,6\%). W Australii w latach 1997-2001 pogłowie owiec zredukowano o $4 \mathrm{mln}$ sztuk, a mimo to produkcja mięsa zwiększyła się. Zaistniałą sytu- 
ację można tłumaczyć przeznaczeniem likwidowanych owiec na rzeź. Spadek produkcji mięsa nastapił w Wielkiej Brytanii (o 19,6\%) i Francji (o 14,8\%). Kraje afrykańskie odnotowywały wzrost produkcji mięsa owczego i koziego.

Tabela 4

Produkcja mięsa owczego i koziego na świecie w latach 1997-2001

\begin{tabular}{|l|r|r|r|r|r|}
\hline \multirow{2}{*}{ Wyszczególnienie } & \multicolumn{5}{|c|}{ Produkcja mięsa w latach [tys. ton] } \\
\cline { 2 - 6 } & 1997 & \multicolumn{1}{|c|}{1998} & \multicolumn{1}{c|}{1999} & \multicolumn{1}{c|}{2000} & \multicolumn{1}{c|}{2001} \\
\hline Swiat & 10569,2 & 10923,3 & 11052,9 & 11425,6 & 11528,2 \\
\hline Chiny & 2132,4 & 2350,0 & 2517,0 & 2743,7 & 2931,1 \\
\hline Australia & 575,0 & 624,2 & 636,5 & 690,6 & 723,1 \\
\hline Zachodnia Sahara & 692,0 & 694,0 & 701,0 & 715,0 & 715,0 \\
\hline Indie & 680,5 & 687,6 & 694,0 & 696,2 & 699,4 \\
\hline Nowa Zelandia & 544,4 & 546,7 & 518,5 & 534,3 & 563,8 \\
\hline Wielka Brytania & 321,0 & 351,0 & 361,0 & 359,0 & 258,0 \\
\hline Hiszpania & 245,1 & 249,7 & 238,2 & 251,1 & 253,9 \\
\hline Nigeria & 220,4 & 222,6 & 228,6 & 226,3 & 226,3 \\
\hline Algieria & 178,9 & 179,2 & 175,5 & 176,4 & 177,3 \\
\hline Francja & 149,9 & 144,4 & 138,3 & 140,0 & 141,8 \\
\hline
\end{tabular}

Źródło: opracowanie własne na podstawie FAOSTAT.

Owce dostarczają wełny, mięsa, skór oraz mleka. W tabeli 5 przedstawiono produkcję mleka - ważnego i prozdrowotnego produktu otrzymywanego od owiec. Produkcja mleka na świecie w analizowanym okresie uległa obniżeniu o około 4,5\%. Największym producentem były Chiny, mimo spadku produkcji w 2001 roku o 9,3\% w stosunku do 1997 roku. Pierwsza pozycję Chiny moga stracić na rzecz Włoch, które zwiększyły produkcję mleka w latach 1997-2001 o $12,1 \%$. Godnym zauważenia jest fakt, że w pierwszej dziesiątce producentów mleka owczego znajduje się aż sześć państw europejskich.

Produkcja mleka owczego w zdecydowanej części państw uległa spadkowi. Za przykład moga posłużyć takie kraje, jak Turcja, Grecja, Hiszpania, Rumunia. Na stałym poziomie produkcję mleka utrzymywała Francja, mimo redukcji pogłowia o $1 \mathrm{mln}$ sztuk.

Mleko może stać się drugim po mięsie według ważności produktem pozyskiwanym od owiec. Istnieje duża szansa stworzenia nawyku konsumpcji mleka owczego. W Polsce i Słowacji mleko owcze jest przetwarzane i uzyskuje sie takie produkty, jak: oscypek, bryndza, bundz. Barierą zniechęcającą do konsumpcji mleka owczego jest wysoka cena. Na rozwój rynku produktów mlecznych pochodzących od owiec duży wpływ będą miały prozdrowotne właściwości tych wyrobów. 
Tabela 5

Produkcja mleka owczego w poszczególnych krajach w latach 1997-2001

\begin{tabular}{|l|r|r|r|r|r|}
\hline \multirow{2}{*}{ Wyszczególnienie } & \multicolumn{5}{|c|}{ Produkcja mleka w latach [tys. ton] } \\
\cline { 2 - 6 } & 1997 & \multicolumn{1}{|c|}{1998} & \multicolumn{1}{c|}{1999} & \multicolumn{1}{c|}{2000} & \multicolumn{1}{c|}{2001} \\
\hline Świat & 8167,0 & 8157,9 & 8038,3 & 7703,1 & 7801,3 \\
\hline Chiny & 1074,0 & 824,0 & 893,0 & 847,0 & 974,0 \\
\hline Włochy & 758,5 & 867,0 & 850,0 & 850,0 & 850,0 \\
\hline Turcja & 826,3 & 813,0 & 805,0 & 774,4 & 723,3 \\
\hline Grecja & 722,2 & 729,9 & 654,0 & 700,0 & 670,0 \\
\hline Syria & 523,8 & 581,9 & 445,9 & 445,6 & 482,8 \\
\hline Rumunia & 370,7 & 354,7 & 342,4 & 321,5 & 323,7 \\
\hline Hiszpania & 326,4 & 342,0 & 305,0 & 306,0 & 306,0 \\
\hline Iran & 412,0 & 463,0 & 549,0 & 288,8 & 295,2 \\
\hline Francja & 243,0 & 242,5 & 243,9 & 246,7 & 245,7 \\
\hline Algieria & 175,0 & 180,0 & 220,0 & 180,0 & 200,0 \\
\hline
\end{tabular}

Źródło: opracowanie własne na podstawie FAOSTAT.

\section{Podsumowanie}

Pogłowie owiec na świecie w latach 1997-2001 uległo niewielkiej redukcji (spadek o $5 \mathrm{mln}$ sztuk). Wraz ze zmniejszeniem się liczby owiec na świecie zmniejszyła się produkcja skór i wełny. Wełna stała się marginalnym produktem, tak samo jak skóry. W skali światowej wzrosła natomiast produkcja baraniny, a mleka utrzymała się na stałym poziomie. Produkcja wełny, mleka i mięsa $\mathrm{z}$ reguły determinowana była pogłowiem owiec. W nielicznych krajach wystapiły jednak wyjątki od tej zasady. Za sztandarowy przykład może posłużyć Australia, gdzie mimo spadku pogłowia o $4 \mathrm{mln}$ sztuk produkcja mięsa wzrosła.

\section{Literatura}

KOMOROWSKA D. (2003): Aktualna sytuacja i perspektywy rozwoju rynku baraniny i jej produktów. Szkolenie nt. prowadzenia i rozwoju gospodarstw specjalizujących się $\mathrm{w}$ produkcji jagniąt rzeźnych $\mathrm{w}$ aspekcie racjonalizacji wykorzystania podstawowych czynników produkcji (pracy, ziemi, kapitału i zarządzania). SAPARD PL-6-02/00, Warszawa, s. 15.

NIŻNIKOWSKI R. (1996): Przydomowy chów owiec. MULTICO Oficyna Wydawnicza, Warszawa, s. 35. www.fao.org. FAOSTAT DATABASE $z$ dn. 20.04.2003. 


\section{The Situation of the World's Sheep Market in the years 1997-2001}

\section{Abstract}

Stock of sheep in the world has fallen off insignificantly in the years 1997-2001 . Changes took a stand along with changes of stock in production. Production of wool decreased, while production of meet increased. Such a situation was related to the permutation of the use of sheep meat. Changes in production of wool and milk were correlated with changes in stock of sheep. 